\title{
Adaptive Governance: Implementation of Green Open Space Program
}

\author{
Muchlas M. Tahir \\ Universitas Muhammadiyah Makassar \\ Makassar, Indonesia \\ muchlasmtahir7@gmail.com \\ Zulfan Nahruddin \\ Universitas Muhammadiyah Makassar \\ Makassar, Indonesia \\ zulfannahruddin@gmail.com \\ Dian Ekawaty \\ Universitas Hasanuddin \\ Makassar, Indonesia \\ Eka.dian16@yahoo.com
}

\begin{abstract}
This study aims to find out how maximum the Implementation of Green Open Space Program in Makassar. It's a descriptive qualitative research, using the type of research fenomenology. Sampling technique used are purposive and snowball sampling. Data collection techniques used observation, interviews, and documentation. Result shows fully adaptive potential capacity not maximized and not in accordance with local regulation 6,2006 , seen from the numberof green public spaces in Makassar really different from the planning side,seen from insufficient green space. Environment's also not inline with local regulatio 6, 2006 article 49, existing environments condition haven't shown good environment. It's inline with Makassar regulation 6, 2006 article 2, paragraph 1-2. Green open space equipped with various facilities indirectly increase social interaction and relations within communities and as means of education introduction, it's inline with Bylaw 6, 2006 Article 50. Optimizing space policy implementation of Green Open Space, expected forming synergy between parties, government and society.
\end{abstract}

Keywords - Adaptive Governance, implementation, GOS

\section{INTRODUCTION}

Green Open Space is an elongated area / line and / or in groups, which the use is more open, where the plants grow, both of which grow naturally or are deliberately planted. (minister's regulation PU No 5 / PRT / M / 2008).The city as a center of growth, development and change as well as the center of economic activities, social, cultural, political, legal and security defense occupies a very strategic position in our national fabric. So that the arrangement and space utilization urban areas need special attention, especially in relation to the provision of residential areas, public facilities and public open spaces (open spaces) in urban areas. In this case, it is neccessary for alignment of the utilization of space in the form of study in the form of rules that are binding on the government [1].

The conditionof Green Open Space in the city of Makassar has decreased over time in line with the development of a dynamic city. Changes in environmental conditions are getting worse and so much the shortage of land with a percentage of $7.236 \%$ of the total area of Makassar to build trees or reforestation area. The discrepancy between the Law No. 26 Year 2007 concerning the provision of spatial planning and utilization of green open space, which is the proportion of its range set at least 30 percent of the area of the city with green open space conditions in the city of Makassar [2].

Whereas in the study [3] The need for green space in an urban required to achieve $30 \%$ of the total area consisting of $10 \%$ GOS $20 \%$ Private and public green space. Achievement of green space by $30 \%$ to overcome the negative effects that will appear in the Territory, but in reality GOS exist in Makassar is not as expected, because the existing GOS is only $5 \%$, while in a utilization of open space in a settlement will be instrumental effective and useful if it contains an element of comfort, relaxation both passive and active, and besides that the open space is also capable of high economic value.

Problems of Green Open Space (GOS) in Urban today is one difficult problem to be solved in the big cities. GOS problem occurs because of the need for space to accommodate the population and activities, so that the space is likely to undergo conversion for land to be developed done without regard to the existence of the surrounding environment. The reduced quantity and quality of public open space in urban areas, either in the form of green open space (GOS), has resulted in decreasing quality of the urban environment such as frequent flooding in urban, high air pollution, and increased social insecurity (crime and social crisis), decreasing public productivity due to stress because of the limited available public spaces for social interaction [3].

Walker in [4] revealed that Adaptive Governance is an evolving framework for analyzing research institutions and ecology of multilevel governance mode was successful in building resilience to face the enormous challenges posed by increasingly complex global changes. The adaptive capacity broadly defined as the ability of the socio-ecological system (or components of the system) to be robust against interference and capable of responding to changes.

Nowadays, it is very important to build a green city in the middle of the city therefore fundamental policies and strong commitment to building sustainable cities are necessary (Green city). Approach to building green city should be 
carried out by combining a healthy economic growth and friendly environment (pro green growth), increase social welfare (pro-poor), providing friendly workplace environment (pro green jobs), and the frames to preserve the environment (pro environment) green city is a city that was built with the advantages of Indonesia which has a tropical climate and unique ecosystems, and green city is a city of healthy and friendly [5].

The importance of green open space (GOS) is regulated in the Code of green open space (GOS) in Urban Area (minister's regulation PU No. 5 / PRT / M / 2008) [6]. Provisions concerning the supply and use minimal green space in an area of town / urban areas is $30 \%$, by assumption $20 \%$ should be provided by the Government of Regency / City and $10 \%$ provided by private or public. Spatial planning of urban areas was organized to: achieve spatial urban areas that are optimal, harmonious and balanced with development of human life. Aware of the benefits and functions of green space that is so important in the activity of the Urban and society, therefore the Government should pay more attention, so that there is not distracted GOS functioned. This is contrary to efforts to achieve sustainable development in urban areas, among others, must meet the criteria of pro social justice spatial planning of urban areas should receive special attention, especially as related to the arrangement and use of space and public facilities Mardin in [3]. Added another in [7] that the comprehensive determination GOS city should be based also on the study of the existence of natural resources and human inhabitants. Determination of the amount of green space area can also be referred to as part of the development of city green space.

Developing green areas built downtown area targeted at $5 \%$ (five percent) from the downtown area: Preserving parks residential area of the center as well as the gardens of the city as well as increasing green space integrated sports region. The presence of green open space is really good for the people of Makassar, besides functioning to prevent flooding, can also serve as a deduction from air pollution that is the presence of plants or trees that absorb a lot of carbon dioxide into the air is dirty or clean air or oxygen. Besides green open spaces can also reduce noise by means plants or trees absorb the sound through the leaves, branches, and twigs in the city of Makassar [2].

The evidence suggests, green open space in the city of Makassar has only reached $10 \%$ of the $30 \%$ requirement, even the study of JICA (Japan International Cooperation Agency) revealed that only $3 \%$ of green space area of the vast city of Makassar were $1775.77 \mathrm{~km} 2$. This differs from the plan that has been set in the existing legislation [8].

Considering the various problems caused by the lack of green space so that it appears the various impacts such as flooding on the highway as well as the number of garbage that littered the streets and the lack of creation of the beauty of the urban environment so it does not directly affect the value of existing beauty and declining economic value because of the presence of the city that has the beauty will appeal to everyone, which would certainly contribute economically. Crack down on the contents of the set-up of Regional
Regulation (Perda) 6 of 2006 on spatial planning Makassar city [12], therefore the researchers are interested in examining the extent to which the program of implementation of green space in the city of Makassar.

\section{RESEARCH METHODOLOGY}

This type of research is descriptive qualitative research method is based on the philosophy of post-positivism, is used to examine the condition of natural objects, (as an opponent) where the researcher is a key instrument, data collection techniques performed triangulasi (combined), data analysis is inductive / qualitative and qualitative research results further emphasize the significance rather than generalizations [9] This study uses this type of approach phenomenology as they relate directly to the symptoms that arise around the research. Source of the data was obtained directly from the field research site such as office layout, landscaping section and the local community in the city of Makassar. The sampling technique used in this research is purposive sampling and snowball sampling. Then the data collection techniques using observation, interviews, and documentation. The results of the study and then interpreted by a qualitative sentence. The results of the data analysis will serve as a final conclusion in the study described by (1998) in Moleong [10] that the data analysis techniques have some process that is noted, Collecting and think, with the way that the categories of data has a meaning, seek, and require a pattern and relationships and make other findings. This research is the extent to which the policy browse through green open space as stipulated in Local Regulation Makassar City has been implemented.

\section{RESEARCH FINDINGS \& DISCUSSION}

Potential adaptive capacity is the government's ability to adapt to the situation at hand is now to be robust against interference and is able to respond to changes in socioecological system, in this case in question is the management of green open space / RTH (Open green space). In terms of its own potential adaptive capacity in urban green open space consists of Green Open Space Public and private green open space; the proportion of green open space in urban areas is at least $30 \%$ of $20 \%$ of public green open space and $10 \%$ consists of private green open space; once the extent of green open space, both public and private in the city in question have a total area larger than regulation or legislation, then that proportion must be maintained.

In the implementation of spatial planning, the next city government itself has referred to the new operational guidelines, the Government Regulation 26, 2008. In connection with the provision of open space through the results of the authority granted by the Central Government's attitude and actions as well as customized in the Law on Spatial Planning then in the implementation includes planning, control and utilization of urban space in an attempt to get the green open space of at least $30 \%$ of the area of the city with a minimum standard of $20 \%$ to $10 \%$ of public and private fulfilled. 
Based on interviews with informants related Potential of adaptive capacity is not fully maximized and not in accordance with Government Regulation 26, 2008. In connection with the Spatial Planning then in it's implementation consist of planning, control and utilization of urban space in an attempt to get the green open space of at least $30 \%$ of spacious city with the minimum standard of $20 \%$ for the public and $10 \%$ filled by private and Regional Regulation 6, 2006 article 15, paragraph 1, which sounds the development of protected green area through regional development in accordance with the function. This condition is seen from the number of open green space in the city of Makassar are very much different from the planning side. Then, In terms of utilization of urban green open space can be said to be less, the reality is seen from public activities in the utilization of open green space.

Based on interviews and observations conducted by directly viewing the environmental conditions that exists, the researchers drew the conclusion that it was indeed the number of green open space in the city of Makassar is still less than what was planned in the PP 26 of 2008 and Regulation No. 6 of 2006 article 15, paragraph 1 . Because in the regulations and Government Regulation is set that the vast green space in a city is $30 \%$ of the existing city. This is evident from interviews conducted with people who say that the amount of green space in the city of Makassar is still less. This indicates that the process of interaction of government and society in the context of governance, which sees the need of a process of social and political interaction between governments with the society in various fields Relating to the public interest and government intervention on the interests of the Kooiman in Mustafa [11]. However, in this study the interaction between the government and the public has not shown any significant change of the implementation of green space in accordance with Regulation 26 of 2008 and Regulation 6 of 2006 Article 15 , paragraph 1 .

Based on interviews and observations conducted by directly viewing the environmental conditions that exists, the researchers drew the conclusion that it is true that the existing hygiene in the area is still lacking, there is still a lot of garbage scattered all over the place and is also incompatible Bylaw 6, 2006 article 49 which describes the management of green areas protected by preserving natural ecosystems. So the local government and the people carrying out voluntary work in order to create an environment that is clean, and the harmony of the environment that has no impact on things like disease and affects water levels, as well as the lack of public awareness until the janitor encounter obstacles in carrying out their duties.

Based on the interviews it is known that the environment which is not conducive could also lead to flooding. So that people feel a sense of insecurity, anxiety and worry the water will seep into their home as the floods because if the water flows into the house will lead to their property endangered and suffered losses, besides floods can also have an impact on the damage of the road, where the water is always puddles on the road with a long time can damage the asphalt road and make the way be hollow thus be prone to accidents, and flood also could make public loss their time as some activities will be stopped due to the floods.

Lack of cleanliness is not the one that caused a decline in environmental quality but floods also one of the factors causing environmental imbalance. Therefore to keep the ecological environment, let us together to preserve the environment for the better. By improving the quality of green open space. Based on the interview is known that in the rainy season and flooding besides water flooded some residential areas and stagnant water also seeps up to the public road. Obviously the impact is very disturbing for residents and road users where when stagnant water with high enough volume that it could damage the vehicle's engine and lead to road congestion and deter the activities.

Based on the interview is known that flooding only occurs at certain points, but when the rainy season arrives the high volume level of water commemorate a specific area of the region and flood puddles seeping up onto the highway / main street. But the flood that occurred cause various diseases and germs and insects as well as will be a lot of mosquitoes and various mushrooms. The interview will also explain that on a personal flood makes restless. But with the the high volume level of stagnant water and still can recede is not the flooding problems which needs to worry, but if the water on high volume and not low tide where there is no room for the flood waters, then it's categorized flood.

Based on interviews and observations conducted by directly viewing the environmental conditions that exists, researchers drew the conclusion that it is true that floods only occur at specific points just on low rainfall, and perk up on the highway / main street and lead to stagnant water, but during the rainy season with high rainfall then almost all the area will be inundated with water, that means it is also not in accordance with Regulation 6, 2006 article 49 which describes the management of protected forest areas and prevent water pollution.

Based on observation, seeing the area was a little dry and very dusty with some transport materials that always crosses the region, which can lead to air pollution, besides people feel the presence of air pollution, although there are several different opinions saying that the problem of air pollution that is existing can still be overcome therefore the researchers concluded that it is in line with Pemendagri No. 1/2007 Article 2 that the Green Open Space are the lungs of the city and ecological balance serves to create a micro-climate and oxygen supply, improving air quality and clean water supply.

Based on the interview explained that the green open space can be utilized as a venue for events such as folk festival, fairs and concert festival. This condition indirectly provide increased economic as well as people who are in the surrounding area who has a profession as a pedicab driver and will feel the impact of the events carried on because visitors can only use their services and the provision of tools used at concerts and festival participants also feel the same as well as traders in the vicinity will be whittle the clappers. 
From the interview earned the explanation that hold a variety of events and activities in the open space will provide a different atmosphere and all societies can watch, and economical because normally free compared by the event which is held at hotel / building which is very expensive because it must have a ticket and not all people can enjoy / watch. This is in accordance with regulation 6, 2006 In article 2, paragraph 1 and 2 that the scope of the green area of the city covered by the strategy and structure of spatial use of Makassar city.

Based on interviews and observations conducted by directly viewing the environmental conditions that exists, the researcher finds a good impact on presence of green open space that indirectly gives benefit from the various parties, it is in conformity by regulation of Makassar 6 Years 2006 article 2, paragraph 1 and 2 . it should will make us always maintain the quality of the environment because by seeing things that happen then no need to doubt that protecting the environment will provide a better impact. Green Open Space is needed in the region, not only provide physical function and architectural but also provide ecological functions and economical [5] As is the case today that people can take advantage of a variety of places to interact, because influenced by lifestyle and many public facilities which are provided that can be used.

Based on the results of interviews earned the explanation that the environment of green space will be beneficial to the social field, because it can increase social interaction between human society and the place to gather with family, friends and collegially where used to spend time to know each other, another benefit is a place to introduce children to basic education on various environmental and other living creatures such as the flora and fauna that exist in the environment and give an understanding of the importance of environment and maintaining environmental balance.

From interviews is known that social interactions can even be intertwined by through religious activities that sometimes carried on in an open space, where the interaction happens is knowing each other and even a few people can see you inadvertently by friends or relatives.

The results of the interview explained that the open space which is provided certainly have their benefits and their role where open spaces are equipped with various facilities aim to provide convenience to every citizen and good relations between the society and also will give the impression of beauty to the city. This is in accordance by Regulation 6 of 2006 Article 50 concerning the use of protected green areas, the downtown area would provide benefits and as a place for people to socialize in order to give aesthetic value and provide benefits as a shade.

Based on interviews and observations conducted by directly viewing the environment and the various opinions that exist, researcher drew a conclusion that green open space that exists and varied and are equipped with various facilities, indirectly increases social interaction and good relations among the society and can even be used as introduction of education, it is in line with Regulation 6 of 2006 Section 50.
Overall the number of green open space in the city of Makassar are very much different from the planning side. This is evident from the insufficient number of green space in the city of Makassar. The observation result also shows that there are circumstances in which it is true that cleanliness that exist in the area under investigation is still lack. researcher found a good impact on the green open space that directly does not gives benefit. Existing green open space and varied and are equipped with various facilities indirectly increase social interaction and good relations among society and can even be used as a means of introduction of education. Judging from Adaptive governance concept which is an approach designed to address the uncertainties inherent in the system in response to change. It has also been seen as an alternative to manage the resources that focus on optimizing certain aspects of the ecosystem according to the needs of current economic or political purposes [13]. Has not been able to be optimized especially in the management of existing resources is not yet optimized. According to Abidin [14] implementation process related to two main factors, those are internal factors and external factors. Internal factors are the policies to be implemented, while external factors are environmental conditions and related parties. Internal factors associated with Adaptive governance particularly related to social interactions that were once only established through activities / common interests and their relations relatives and constrained by the rules and not in the various places anywhere, unlike now that people can now take advantage of a variety of places to interact, because it is influenced by lifestyle and many public facilities that are provided that can be used.

In the end, the study found that a number of indicators Adaptive governance is not maximal enough in terms of implementation, it is seen from the lack of the amount of green space in the city of Makassar and still spinning on the state of the environment which is not yet managed because still preoccupied with the problem of flooding, cleanliness and air pollution. But the positive side that exists is a social relation that is built on the presence of green space provides social impact for the community though in terms of policy implementation has not been implemented optimally.

\section{CONCLUSION}

Adaptive governance in terms of potentials fully adaptive capacity is not maximized and not in accordance with in accordance with Regulation 6 of 2006 Article 15, paragraph 1, which reads the protected green area development through regional development in accordance with the function. This condition is seen from the number of open green space in the city of Makassar are very much different from the planning side. This is evident from the lack of the amount of green space in the city of Makassar. Environmental governance: In relation to environmental governance It is also not in accordance with Regulation 6 of 2006 article 49, the observation results also show that there are circumstances in which it is true that cleanliness that exist in the area under investigation is still lacking. Associated with the practice, Seeing a good impact on their green open space that does not 
directly benefit from the various parties there it is in compliance with Regulation Makassar City 6, 2006 article 2, paragraph 1 and 2 . In the important relationship between the indicator changes global (social) note that the existing green open space and varied and are equipped with various facilities indirectly increase social interaction and good relations within society and can even be used as a means of introduction of education, it is in line with Bylaw 6, 2006 Article 50. for the future expected their empowerment in protecting the environment and improving health as a form of synergy between the various parties in order to optimize policy implementation GOS.

\section{REFERENCES}

[1] Ariyanto. (2015). Landasan Program Perencanaan \& Perancangan Arsitektur Apartemen di Jakarta. Semarang: Universitas Diponegoro.

[2] Rakhmatsyah, Asrul. (2015). Dampak Kebijakan Ruang Terbuka Hijau di Kota Makassar, Administrasi Publik, Vol.1, no. 2

[3] Ansir, Rasmi. (2015). Evaluasi Kebijakan Ruang Terbuka Hijau (RTH) di Kota Makassar. Universitas Muhammadiyah Makassar.

[4] Armitage, Derek and Pummer, Ryan. (2010). Adaptive Capacityand Environmental Governance", Springer : New York.

[5] Joga, Nirwono (2013). Gerakan Kota Hijau. PT. Gramedia Pustaka Utama Anggota IKAPI : Jakarta.

[6] Peraturan Menteri Pekerjaan Umum Nomor 05/PRT/M/2008 Tentang Pedoman Penyediaan dan Manfaat Ruang Terbuka Hijau di Kawasan Perkotaan.

[7] Wibowo, Sulistyo. (2013). Implementasi Ketentuan Penyediaan Ruang Terbuka Hijau Berdasarkan Pasal 29 Undang - Undang Nomor 26 Tahun 2007 Tentang Penataan Ruang. Surakarta.

[8] Salam, Ekawaty Sukma. (2012). Implementasi Penataan Hutan Kota dalam Mewujudkan Ruang Terbuka Hijau di Wilayah Kota Makassar. Makassar.

[9] Sugiyono. (2014). Metode Penelitian Kombinasi (Mixed Methods). Alfabeta : Bandung.

[10] Moleong, L.J. (2012). Metodologi Penelitian Kualitatif. Bandung: PT Remaja Rosdakarya.

[11] Mustafa, Delly. (2013). Birokrasi Pemerintahan. Alfabeta: Bandung.

[12] Peraturan Daerah Kota Makassar Nomor 6 Tahun 2006 Tentang "Rencana Tata Ruang Wilayah Kota Makassar Tahun 2005-2015".

[13] Cosens, B. A., and M. K. Williams. (2012). Resilience and water governance: adaptive governance in the Columbia River basin. Ecology and Society Vol. 17, no. 4,

[14] Abidin, Said Zainal. (2012). Kebijakan Publik. Yayasan Pancur Siwah : Jakarta. 